\title{
THE ENERGY DISCLOSURE AMONG ENERGY INTENSIVE COMPANIES IN MALAYSIA: A RESOURCE BASED APPROACH
}

\author{
Nabila Elyana Tasrip, Norhayati Mat Husin, Bakhtiar Alrazi* \\ *Department of Accounting, Universiti Tenaga Nasional, Sultan Haji Ahmad Shah Campus, 26700 \\ Muadzam Shah, Pahang, Malaysia
}

\begin{abstract}
This study examines the extent of, and factors influencing, energy disclosure in Malaysia. We content analysed the annual reports of top 100 energy intensive companies for the year 2014 . Using resource-based theory, we analysed if companies' tangible and intangible resources as well as human capabilities determine the extent of energy disclosure. Overall, the disclosure is low with an average 'occurrence' of energy-related information of 3.53. We also find that the 'Top Brand Value' companies and companies with a larger number of directors serving on the board tend to provide greater energy disclosures. However, other variables - in particular tangible resources - have no significant influence. The findings provide tentative evidence to support the arguments of resource-based theory.
\end{abstract}

Keywords: energy reporting, resource-based theory, Malaysia.

\section{INTRODUCTION}

The world economic and industrial development brings along negative environmental impacts such as climate change and global warming (Akbas and Canikli, 2014). The rising use of fossil fuels continues to increase energy-related carbon-dioxide $\left(\mathrm{CO}_{2}\right)$ emissions. A report by International Energy Agency (2013) indicates that the Southeast Asia's energyrelated $\mathrm{CO}_{2}$ emissions had almost doubled, from 1.2 gigatonnes (Gt) in 2011 to $2.3 \mathrm{Gt}$ in 2035 , or from $3.7 \%$ to $6.1 \%$ of global emissions. Additionally, the total electricity net consumption had increased from 109.834 billion $\mathrm{kWh}$ in the year 2010 to 115.338 billion kWh in the year 2011 (International Energy Outlook, 2014).

Malaysia is an example of developing country in the East Asian region as there is rapid growth in the economic environment (Arshad et al., 2012). It is known as the world's secondlargest exporter of liquefied natural gas and the second-largest oil and natural gas producer in Southeast Asia as reported in the website of U.S Energy Information and Administration. In year 2012, the electricity production in Malaysia stood at 118 billion $\mathrm{kWh}$ and consumption at 112 billion $\mathrm{kWh}$. The growing electricity demand has spurred the use of fuels such as coal, oil, and gas. Commercial and residential buildings alone accounted for about $13 \%$ of total energy consumption and $48 \%$ of electricity consumption in Malaysia (Al-Mofleh et al., 2009). The increase in the consumption of energy and fossil fuels will eventually lead to emissions released to the atmosphere. Hence, estimation of energy consumption for operating household appliances, savings of energy under policy intervention, and emission of poisonous gases in a fast developing country deserve academic attention (Saidur et al., 2007).

\footnotetext{
*Corresponding author's email: Bakhtiar@uniten.edu.my
} 
Among the mechanisms that have been instituted by the government of Malaysia to mitigate the emissions build up are energy efficiency and the use of renewable energy. For example, Sustainability Achieved via Energy efficiency (SAVE) was introduced in 2011 to encourage the purchase of energy efficient equipment to initiate market development of energy efficient appliances by giving rebates. Moreover, the establishment of Sustainable Energy Development Authority Malaysia (SEDA) and Green Technology Financing Scheme (GTFS) are examples of government initiatives regarding renewable energy. In a similar vein, companies are expected to undertake initiatives to reduce their environmental impacts from energy-related activities and to report them to the public. The reporting of such information can be done through annual reports, stand-alone sustainability reports, and the websites.

Unlike the literature on generic environmental reporting and later on carbon reporting, there are limited studies focusing on the reporting of energy information. To date, only Maneschijn et al. (2014) focused specifically on energy reporting; however it is not conducted on Malaysia. Additionally, most of prior literature in social and environmental reporting had relied on legitimacy theory to explain the reporting practice. The use of alternative theoretical lens is thus needed.

The objectives of this study are twofold. Firstly, it aims to explore the extent of energy disclosure made by energy intensive companies in Malaysia. In this regard, a checklist instrument is constructed to measure the quantity of energy related items being reported in the annual reports, stand-alone reports and also the corporate websites. Secondly, using resource based theory, it aims to examine the influence of tangible and intangible resources as well as human capabilities on the extent of energy disclosure.

The study is pertinent for several reasons. This study will be the first attempt in providing evidence of energy reporting in Malaysia. In so doing, it adds to the body of knowledge which had placed greater emphasis on the reporting of general environmental information and carbon information. It also contributes in using resource-based theory as an alternative explanation for the disclosure practice. The constructed checklist instrument could be used by researchers for conducting further studies and for companies to identify the information they might consider for reporting. Finally, the findings will provide indication for the policy makers to revisit the requirements for energy reporting in Malaysia hence to improve the existing energy-related policy frameworks.

The remaining sections of the paper are structured as follows. Section 2.0 provides the discussion of related literature and hypotheses development. Section 3.0 presents the research methods. Section 4.0 discusses the findings. Section 5.0 concludes the paper.

\section{LITERATURE REVIEW AND HYPOTHESES DEVELOPMENT}

\section{Literature review}

Malaysian government has embarked on various strategies to enhance its' energy-based initiatives. The most prominent strategy is the introduction of various energy based policies. Among those are the introduction of National Energy Policy (1979), National Depletion Policy (1980), National Biofuel Policy (2006), National Green Technology Policy (2009), and National Renewable Energy Policy (2010). Currently, a final draft of National Energy Efficiency Action Plan is introduced in January 2014. The plan outlines strategic actions that 
are needed for an effective and efficient implementation of energy efficiency programs. The introduction of National Green Technology Policy (2011-2015) provide details on the strategy to restructure the energy subsidies on natural gas and electricity used by industry sector as well as discounted energy pricing mechanism for selected industrial users. With several energy policies being implemented by the government that acts on behalf of the public, this means a company is now being bequeathed with legitimacy based on its ability to operate within the bounds imposed by the society in order to enjoy continued access to products and resource markets (Campbell et al., 2003). Corporate reporting, therefore, has become one of the strategies used by companies to educate the public or to communicate the changes that have been made, in response to the pressure made by the government/public to contribute to energy-based initiative. Nonetheless, with financial reporting being the center of attention since the existence accounting, the reporting of non-financial based information in Malaysia has only been made compulsory in year 2007 with the mandatory requirement of Corporate Social Responsibility (CSR) reporting to all Malaysian public listed companies (PLCs) (Sulaiman et al., 2014).

Prior studies on climate change reporting (see for example De Aguiar and Bebbington, 2014; Ahmad and Hossain, 2015), CSR reporting (see for example Othman and Ameer, 2009; Salleh et al., 2010) and environmental reporting (see for example Ienchu et al., 2012; Sulaiman et al., 2014) are among studies that have evaluated companies disclosure, in response to pressure resulting from social contract, in different forms of corporate reports. Most of these studies have also incorporated energy based information as part of the information being evaluated. A CSR reporting study conducted by Ahmad et al. (2003), for example, reported only small minority (1 percent) of companies in industrial sector disclose information related to on energy. Nonetheless, with energy-based information being incorporated with other types of sustainability information, the analysis can be regarded as being very limited. To the knowledge of this study, there is only one study that put a specific focus on energy reporting and it is conducted by Maneschijn et al. (2014). This study which is based in South African developed a guideline for the development and implementation of effective energy reporting. Unfortunately, Maneschijn et al. (2014) only focuses on preparing a special energy report for a company' energy management system that may not be able to represent overall energy initiatives implemented by the company. Taking into consideration the importance of energy conservation issue in Malaysian and the lack of focus on energy reporting per se, it is the objective of this study to provide a close examination of energy information reported by top energy intensive companies in Malaysia.

\section{Theoretical Framework and Hypotheses Development}

\section{Resource-Based Theory}

The resource based theory (RBT) serves as the theoretical foundation of this study. The general argument for this theory is that companies need to have resources for them to implement any strategies and to achieve competitive advantage. In this regard, previous scholars have attempted to categorise the resources. Russo and Fouts (1997) classified resources into (1) physical assets and technology, (2) human resources and organisational capabilities and (3) intangible resources such as reputation and organisation's political acumen. Das and Teng (2000) identified two major types of resources: (1) property-based resources and (2) knowledge-based resources. Branco and Rodrigues (2006) suggested the following categories of resources: (1) tangible resources (financial assets and physical 
assets); (2) intangible resources and capabilities (intellectual property assets, organisational assets, and reputational assets).

In this study, we consider the following: (1) tangible resources (Russo and Fouts, 1997), (2) intangible resources, including corporate reputation (Russo and Fouts (1997), (3) capabilities, including human resources (Wright and McMahan, 1992; Barney, 1991; Russo and Fouts, 1997). In essence, companies with tangible resources (profitability, leverage, and financial slack), reputation, and human capabilities (board size, CEO with international experience, and board with international experience) tend to provide greater extent of energy disclosures.

\section{Hypotheses Development}

\section{Profitability}

Sulaiman et al. (2014) expected that a company with good profitability is perceived to have more resources to provide better quality environmental disclosure. Accordingly, companies with higher profitability may increase the quality of environmental disclosure primarily as they have better means and opportunities as compared to companies with lower profitability. A number of previous studies revealed negative findings on the relationship between profitability and energy reporting. Sulaiman et al. (2014) concluded that profitability had no significant relationship with the quality of environmental reporting. Toppinen et al. (2012) also found no statistically significant association between profitability and voluntary disclosures for the sample companies. One explanation could be the use of single profitability indicator (ROCE) and the cross-sectional nature of data in the study.

Nevertheless, the following researchers reached opposing conclusions (Qiu et al., 2014; Luo et al., 2013). Luo et al. (2013) who studied on carbon disclosure argued that profitable firms are less constrained by financial resources in making green decisions and directly enhance their economic performance as compared to less profitable firms. Qiu et al. (2014) also found being profitable firms have the resources and the willingness to commit to investments in the social arena. The study concludes that profitable firms make higher social disclosure compared to environmental disclosure and higher combined social and environmental disclosure. Based on these arguments, we develop the following hypothesis:

$\mathrm{H}_{1}$ : Profitability is associated with the extent of energy disclosure

\section{Leverage}

Clarkson et al. (2008) suggested that firms with high leverage may not be able to absorb the adverse financial impact of disclosing energy information, due to high financial risk inherent in such disclosures. Luo et al. (2013) revealed that firms in developing countries with higher leverage are less likely to disclose carbon information. Firms with poor financial condition tend to less disclose and bear the consequences of revealing proprietary carbon information. The level of average is negatively associated with disclosure, due to a heavier liability for debt and interest repayment would restrict a firm's ability to undertake strategies for carbon reduction and disclosures and high leverage firms would be more sensitive to carbonprevention expenditures. 
Thus, the following hypothesis is developed:

$\mathrm{H}_{2}$ : Leverage is associated with the extent of energy disclosure

\section{Organisational Slack}

Nohria and Gulati (1996) refer slack as the pool of resources in an organisation that is in excess of the minimum necessary to produce a given level of organisational output. When an excess of available resources exists, businesses are able to invest in socially responsible activities, such as energy reporting, which may enhance the corporate social and environmental performance (Elsayed, 2006). Companies with more slack resources have a wider variety of strategic options compared to a company that have limited resources (Yol Lee and Rhee, 2007). Bansal (2005) recommended that organizational slack allows organisations to engage in creative practices. Whereas inadequate of slack resources limits business flexibility, thus hindering its performance and response to institutional pressures on timely issues such as climate change.

Yol Lee and Rhee (2007) found that slack resources have positive relationship with corporate environmental strategies. Bansal (2005)'s finding shows a positive relationship between organisational slack and corporate sustainability. Recent scholars however found contrary evidence. Amran et al. (2016) indicate that organisational slack is inversely related to climate change business strategy. Darus et al. (2014) posits negative relationship between organisational slack on corporate social responsibility (CSR) of financial institutions in Malaysia. Accordingly, Arshad et al. (2012) find inverse relationship between organisational slack and two types of environmental disclosure; annual report and corporate websites.

The following hypothesis is developed:

$\mathrm{H}_{3}$ : Organisational slack is associated with the extent of energy disclosure

\section{Corporate Reputation}

Corporate reputation is arguably one of the most important intangible assets that provide competitive advantage (Toms, 2002). A good corporate reputation is important to firm performance and such resource is more likely to be valuable and inimitable when society demands a cleaner environment (Russo and Fouts, 1997).

Cao et al. (2012) provided evidence that companies with higher reputations are less likely to misstate their financial statements. Zeng et al. (2012) argue that a company which aims to convey a better image and value its public reputation among stakeholders is more likely to voluntarily disclose environmental information. On the other hand, Steverman (2010) gave an example of British Petroleum (BP), receiving high marks from many influential CSR and sustainability rating agencies between 2001 and 2009, was responsible for the Deepwater Horizon oil spill in the Gulf of Mexico, the worst environmental disaster in the U.S. history.

Therefore, we develop the following hypothesis:

$\mathrm{H}_{4}$ : Corporate reputation is associated with the extent of energy disclosure

\section{Board size}

The board size affects the monitoring ability of the boards and that larger board sizes are often believed to be more capable of monitoring the actions of top management (Amran et al. 
2016) as it will increase the communication problems and cost of poor decision making Mohamad Taha, 2013). A larger board size is assumed to consist of directors with different backgrounds such as education, industrial, knowledge and skills. The combination of various knowledge and skills could help to improve the quality of actions or decisions made. Thus, the hypothesis is developed as follow:

$\mathrm{H}_{5}$ : Board size is associated with the extent of energy disclosure

\section{CEO/Board of directors with international experience}

CEO represents one of the unique resources who lead the organisation by formulating business strategy and implement strategies towards strategic competitive advantage (Slater and Dixon-Fowler, 2009). Wei and Ling (2015) opined that CEOs/boards who have working experience at foreign firms possess higher levels of corporate entrepreneurship than those with CEOs/boards who have worked only at domestic firms. As international assignments mostly hold more responsibility, executives experience higher levels of autonomy, which may instill higher confidence levels (Suutari and Mäkelä, 2007). The international experience which they have gained enabled them to develop a set of best practice based on their collective learning in prior working assignment (Bansal, 2005).

Bansal (2005) further argued CEO/boards with international experience could build up the best practice based on their knowledge obtained from different countries. This is supported by other past studies that have indicated that CEOs' international experience positively impacts business performance (Carpenter et al., 2001; Slater and Dixon-Fowler, 2009). Such experience is considered as tacit knowledge, represent the strategic value for the business and directly leading to higher business performance (Carpenter et al., 2001). Arshad et al. (2012) found that international experience of $\mathrm{CEO} /$ boards is significantly positively related to the extent of environmental reporting in corporate websites.

This is however not the case in Amran et al. (2016). The authors found a negative association and argued that $\mathrm{CEO}$ /board with international experience does not have any advantage over locally experience CEO in formulating climate change business strategy. Additionally, Darus et al. (2014) found a negative relationship between foreign exposure of top management on corporate social responsibility (CSR) of financial institutions in Malaysia.

Hence, the hypothesis is developed as follow:

$\mathrm{H}_{6}$ : $\mathrm{CEO}$ with international experience is associated with the extent of energy disclosure

$\mathrm{H}_{7}$ : Board of directors with international experience is associated with the extent of energy disclosure

\section{RESEARCH METHODS}

\section{Sample selection}

The sample for this study is public listed companies which are among the energy producers and energy intensive industries. The industries classified as energy intensive industries are energy production, wood, glass, rubber, pulp and paper, food, cement, ceramic, iron, steel, chemical, textile, aluminum, and transportation. Table 1 below provides the classification of industries based on their energy intensity according to prior literature. 


\begin{tabular}{ll}
\hline Industry & References \\
\hline Iron \& steel & Song \& Oh (2015); Liddle (2012); Saygin et al.(2011) \\
Cement & Li et al. (2014); Napp et al. (2014); Campana et al. (2013) \\
Chemical & Liddle (2012); Bassi \& Yudken (2011); Saygin et al. (2011) \\
Pulp \& paper & Song \& Oh (2015); Liddle (2012); Saygin et al., (2011) \\
Textile & Bassi et al. (2012); Palamutcu (2010) \\
Aluminum & Li et al. (2014); Liddle, (2012); Bassi \& Yudken, (2011) \\
Oil \& gas & Song \& Oh (2015); Li et al. (2014); Campana et al. (2013) \\
Electricity \& heat & Li et al. (2014); Bassi et al. (2012) \\
Ceramic & Li et al. (2014) \\
Glass & Campana et al. (2013) \\
Wood & Paramonova et al. (2015) \\
Coal mining & Levesque et al. (2014) \\
Transport & Lin \& Xie (2014) \\
\hline
\end{tabular}

Table 1: Energy intensive industries

Since the classification of the industry based on Bursa Malaysia is different, we contacted the officer at Bursa Malaysia to provide a list of companies based on their core activities according to market capitalisation. From the list, we selected the top 100 companies based on the arguments in the literature that companies that are large are more visible to the public hence expected to provide greater disclosures.

\section{Data Collection Procedures}

In conducting this research, the data were extracted from the annual reports, stand-alone reports and also corporate web reports. The annual and stand-alone reports of these companies were accessed through website of Bursa Malaysia and the companies' websites. We used all these media since energy disclosure is considered a new area - both in literature and practice - and to ensure that the disclosure is comprehensive (Unerman, 2000). Data for the year 2014 were used because they are the most recent data available at the commencement of this research.

\section{Energy Disclosure Instrument}

To achieve the first objective in this study, energy disclosure checklist instrument is constructed. The development of this instrument involved scrutinising preliminary indexes of energy efficiency and renewable energy through a review of previous literature (Kansal et al., 2014; Abdullah et al., 2011; Buniamin, 2010) and Global Reporting Initiative (GRI) indicators that are relevant to energy efficiency and renewable energy

Table 2 below shows a self-developed checklist instrument which suits the Malaysian context on energy. 


\begin{tabular}{|c|c|c|c|}
\hline No. & Items & & licators \\
\hline \multirow{5}{*}{1} & \multirow{5}{*}{$\begin{array}{l}\text { Energy } \\
\text { consumption } \\
\text { organisation }\end{array}$} & 1 & Report total energy consumption within the organisation in joules or multiples \\
\hline & & 2 & Report energy consumed outside of the organisation, in joules or multiples \\
\hline & & 3 & Report on energy usage by types (Coal, electricity, etc) \\
\hline & & 4 & Report on energy use by facility or segment level \\
\hline & & 5 & Report the energy intensity ratio \\
\hline \multirow{5}{*}{2} & \multirow{5}{*}{$\begin{array}{l}\text { Initiative to reduce } \\
\text { energy consumption }\end{array}$} & 1 & Development / Usage of energy-efficient products and services \\
\hline & & 2 & $\begin{array}{l}\text { Procedures related to training and raising awareness in relation to the society } \\
\text { aspects }\end{array}$ \\
\hline & & 3 & Have a clear target on energy conservation \\
\hline & & 4 & Disclose relevant technologies (energy management system) \\
\hline & & 5 & $\begin{array}{l}\text { Participation in voluntary environmental initiatives endorsed by Ministry of } \\
\text { Energy, Green Technologies \& Water (MEGTW) or other organisation }\end{array}$ \\
\hline \multirow{3}{*}{3} & \multirow{3}{*}{$\begin{array}{l}\text { Energy governance } \\
\text { \& ethics }\end{array}$} & 1 & Disclosing company's policy on energy \\
\hline & & 2 & $\begin{array}{l}\text { Disclosing governance structure related to energy including committees } \\
\text { [Sustainability and Transformational Management Office] (TMO) }\end{array}$ \\
\hline & & 3 & $\begin{array}{l}\text { Disclose the organisation's values, principles, standards, and norms of behavior } \\
\text { related to energy }\end{array}$ \\
\hline 4 & $\begin{array}{lr}\text { Energy } & \text { based } \\
\text { achievement } & \& \\
\text { awards } & \end{array}$ & 1 & Receiving an award for an energy conservation programme (Environment, etc) \\
\hline \multirow{3}{*}{5} & \multirow{3}{*}{$\begin{array}{l}\text { Reduction of energy } \\
\text { consumption }\end{array}$} & 1 & $\begin{array}{l}\text { Comparison of energy consumption with previous year or reduction target } \\
\text { level }\end{array}$ \\
\hline & & 2 & Report on total energy saving due to direct conservation activities \\
\hline & & 3 & Report the reductions in the energy requirements of sold products and services \\
\hline \multirow{3}{*}{6} & \multirow{3}{*}{ Renewable energy } & 1 & Disclosure on the use of renewable energy sources \\
\hline & & 2 & Disclosure on investment in RE \\
\hline & & 3 & Acquisition of renewable energy certificates \\
\hline 7 & Other disclosure & 1 & Any other energy disclosures not fitting the items above \\
\hline
\end{tabular}

Table 2: Energy disclosure checklist instrument

\section{Measurement of variables}

For this research, the dependent variable is the extent of energy reporting, while the independent variables consist of variables representing the resources available to the companies. We also included two additional variables asset newness and capital intensity as control variables since these two variables have been used in the past to proxy for environmental performance. High asset newness and capital intensity indicate greater proportion of investment in new technologies that might be more environmentally friendly (see Clarkson et al., 2008). Table 3 below summarises the measurement of variables. 


\begin{tabular}{lllll}
\hline Variables & Measurement of variables & References & \\
\hline Dependent Variables & $\begin{array}{l}\text { Occurrence (how many times the } \\
\text { energy related information being } \\
\text { mentioned) }\end{array}$ & $\begin{array}{l}\text { Michelon and } \\
(2012)\end{array}$ \\
$\begin{array}{l}\text { Extent of Energanetti } \\
\text { Reporting }\end{array}$ & - Buniamin (2010) & \\
\hline
\end{tabular}

\section{Independent Variables \\ Resource Based Variables}

\begin{tabular}{lll} 
& Return on asset (ROA) & - Qiu et al. (2014) \\
Profitability & - Sulaiman et al. (2014) \\
\hline
\end{tabular}

Debt to equity ratio Leverage
assets]

\begin{tabular}{|c|c|c|}
\hline $\begin{array}{l}\text { Organisational } \\
\text { Slack }\end{array}$ & $\begin{array}{l}\text { Current ratio [Ratio of current assets } \\
\text { to current liabilities] (CA:CL) }\end{array}$ & $\begin{array}{ll}\text { - } & \text { Amran et al. (2016) } \\
\text { - } & \text { Darus et al. (2014) } \\
\text { - } & \text { Arshad et al. (2012) } \\
\text { - } & \text { Yol Lee \& Rhee (2007) } \\
\text { - } & \text { Bansal (2005) } \\
\end{array}$ \\
\hline \multirow{3}{*}{$\begin{array}{l}\text { Corporate } \\
\text { Reputation }\end{array}$} & Corporate Brand Value & \multirow{3}{*}{ - Zeng et al., (2012) } \\
\hline & $\begin{array}{l}\text { Companies listed in the Top } 100 \\
\text { companies of brand value }=1\end{array}$ & \\
\hline & $\begin{array}{l}\text { Companies not listed in the Top } 100 \\
\text { companies of brand value }=0\end{array}$ & \\
\hline Board size & Number of board members & - Buniamin et al. (2008) \\
\hline $\begin{array}{l}\mathrm{CEO} \\
\text { International } \\
\text { Experience }\end{array}$ & $\begin{array}{l}\text { International experience } \mathrm{CEO} / \\
\text { Chairman }=1 ; \text { No international } \\
\text { experience }=0\end{array}$ & $\begin{array}{l}\text { - } \quad \text { Darus et al. (2014) } \\
\text { - } \text { Amran, et al. (2016) } \\
\text { - }\end{array}$ \\
\hline $\begin{array}{l}\text { Board of directors } \\
\text { with International } \\
\text { Experience }\end{array}$ & $\begin{array}{l}\text { Percentage of board members with } \\
\text { international experience of the total } \\
\text { board of directors }\end{array}$ & $\begin{array}{ll}\text { - } & \text { Amran et al. (2016) } \\
\text { - } & \text { Darus et al. (2014) } \\
\text { - } & \text { Arshad et al. (2012) }\end{array}$ \\
\hline
\end{tabular}

\section{Control Variables}

Ratio of net properties, plant and Asset Newness $\quad \begin{aligned} & \text { equipment } \\ & \text { divided by the gross properties, plant }\end{aligned}$ - Clarkson et al., (2008) and equipment

Capital Intensity $\quad \begin{aligned} & \text { Ratio of capital spending divided by } \\ & \text { total sales revenues }\end{aligned} \quad$ Clarkson et al., (2008)

Table 3: Summary of variables 


\section{Regression model}

The following regression model is used to examine the relationship between the extent of energy reporting and resource-based theory elements which comprise profitability, leverage, organizational slack, corporate reputation, board size, CEO with international experience, boards of directors with international experience, and control variables.

$$
\begin{aligned}
E R E P= & \beta_{0}+\beta_{1} R O A+\beta_{2} L E V+\beta_{3} S L A C K+\beta_{4} R E P U T+\beta_{5} \mathrm{BSIZE}+\beta_{6} C E O E X P+\beta_{7} B E X P+ \\
& \beta_{8} N E W N E S S+\beta_{8} C A P I N+\varepsilon
\end{aligned}
$$

Where:

$\begin{array}{ll}\text { EREP } & \text { : Level of Energy Reporting } \\ \beta_{0} & : \text { Intercept } \\ \text { ROA } & \text { : Profitability } \\ \text { LEV } & \text { : Leverage } \\ \text { SLACK } & : \text { Organisational Slack } \\ \text { REPUT } & : \text { Corporate Reputation } \\ \text { BSIZE } & : \text { Board size } \\ C E O E X P & : \text { CEO / Chairman with international experience } \\ \text { BEXP } & : \text { Board of directors with international experience } \\ \text { NEWNESS } & : \text { Asset Newness } \\ C A P I N & : \text { Capital Intensity } \\ \varepsilon & : \text { Disturbance term }\end{array}$

\section{FINDINGS AND ANALYSIS}

This section presents the findings from the descriptive statistics, correlation analysis, and regression analysis.

\section{Descriptive statistics}

Table 4 depicts the descriptive statistics for the variables used in estimation. Based on the table, the extent of energy disclosure among the sample companies is low with an average occurrence of 3.530. Additionally, the majority of the sample companies consist of profitable $(R O A=0.415)$, highly leveraged $(L E V=1.398)$, and positive working capital $(S L A C K=$ 2.734) companies. Top Brand companies make up only $19 \%$ of the sample (REPUT). In regards to human capabilities, the average number of board members is 8 , with $59 \%$ of the CEO and $44.7 \%$ of the board members have international experience. For control variables representing the degree of environmental performance, NEWNESS and CAPIN, due to the nature of the companies which are high energy intensive, the sample can be considered as having high impact to the environment, with means of 0.655 and 0.807 , respectively. 


\begin{tabular}{lrrrrr}
\hline \multicolumn{7}{l}{ Panel A: Descriptive statistics of continuous variables used in estimation } & & \\
\hline Variable & Mean & Median & Q1 & Q3 & Std dev \\
\hline EREP & 3.530 & 1.000 & 0.000 & 4.750 & 5.290 \\
ROA & 0.415 & 0.060 & 0.025 & 0.100 & 0.207 \\
LEV & 1.398 & 0.465 & 0.138 & 0.878 & 7.121 \\
SLACK & 2.734 & 1.655 & 1.113 & 2.453 & 6.409 \\
BSIZE & 8.490 & 8.000 & 7.000 & 10.000 & 2.1630 \\
BEXP & 0.447 & 0.500 & 3.000 & 6.000 & 0.2138 \\
NEWNESS & 0.655 & 0.637 & 0.498 & 0.793 & 0.2632 \\
CAPIN & 0.807 & 0.426 & 0.248 & 1.106 & 1.4129
\end{tabular}

\begin{tabular}{cccccc}
\hline Panel B: Distribution of categorical variables & \multicolumn{7}{c}{} & \\
\hline \multicolumn{7}{c}{1} & & & 0 & \\
\cline { 2 - 6 } & Variable & 19 & 19 & 81 & 81 \\
REPUT & 59 & 59 & 41 & 41 \\
\hline
\end{tabular}

This table presents descriptive statistics of the dependent and independent variables used in correlation and regression analyses. Statistics are presented for the full sample of 100 companies.

Table 4: Descriptive statistics of continuous variables

\section{Correlation analysis}

Correlation analysis was conducted to determine whether there is a multicollinearity problem that could influence the regression analysis. Table 5 provides the results of the correlation statistics with Pearson above the diagonal and Spearman's rho, below. This is a two-tailed test of significance. There appears to be no serious multicollinearity issues among the independent variables. According to Field (2013), a coefficient correlation of greater than, or equal to, $(\geq) 0.80$ indicates there is cause for concern. Based on the table below, the highest coefficient is $0.505(p=0.000)$ which is between ROA and SLACK.

\begin{tabular}{lcccccccccc}
\hline & EREP & ROA & LEV & SLACK & REPUT & BSIZE & CEOEXP & BEXP & NEWNESS & CAPIN \\
\hline EREP & - & 0.040 & -0.060 & -0.010 & $0.431^{* *}$ & $0.318^{* *}$ & -0.013 & 0.093 & 0.060 & -0.043 \\
ROA & -0.080 & - & -0.074 & 0.008 & 0.025 & 0.214 & -0.120 & -0.193 & 0.041 & 0.042 \\
LEV & 0.071 & $-0.433^{* *}$ & - & 0.136 & -0.036 & -0.108 & 0.095 & 0.193 & 0.082 & -0.055 \\
SLACK & -0.097 & $0.505^{* *}$ & $-0.467^{* *}$ & - & -0.079 & $-0.201^{*}$ & -0.092 & -0.147 & 0.083 & -0.097 \\
REPUT & $0.356^{* *}$ & -0.112 & 0.144 & -0.118 & - & 0.174 & 0.093 & 0.195 & -0.005 & 0.015 \\
BSIZE & $0.356^{* *}$ & 0.056 & 0.081 & -0.139 & 0.193 & - & 0.029 & -0.014 & 0.015 & 0.160 \\
CEOEXP & 0.008 & -0.102 & 0.099 & 0.030 & 0.093 & 0.063 & - & $0.471^{* *}$ & -0.034 & 0.093 \\
BEXP & 0.158 & $-0.232^{*}$ & 0.108 & -0.071 & 0.191 & -0.020 & $0.477^{* *}$ & - & -0.095 & 0.046 \\
NEWNESS & 0.074 & -0.123 & 0.185 & -0.047 & -0.002 & 0.004 & -0.002 & -0.074 & - & 0.124 \\
CAPIN & 0.089 & -0.128 & $0.216^{*}$ & -0.145 & 0.131 & $0.370^{* *}$ & 0.048 & 0.006 & 0.025 & - \\
\hline
\end{tabular}

This table presents the correlation statistics for the dependent and independent variables used in multivariate analyses. Statistics are presented for the full sample of 100 companies. ${ }^{*}$ and $* *$ represent significance levels (two-tailed) at 5 percent and 1 percent, respectively.

Table 5: Correlation statistics for dependent and independent variables

\section{Regression analysis}

Table 6 presents the results of the linear regression (OLS). Each variable's unstandardised coefficients and $p$-values (two-tailed) and each model's adjusted $R^{2}$ and $F$ statistic are provided. Based on the table, the only significant variables are REPUT and BSIZE. These indicate that Top Brand companies and companies with larger board size provided greater

[Type here] 
energy disclosures. This is consistent with the argument of resource-based theory. However, other variables are not statistically significant. The adjusted $R^{2}$ indicates that the variables included in the model are able to explain $19 \%$ of the variation in the extent of energy reporting.

\begin{tabular}{lll}
\hline & \multicolumn{1}{c}{$\beta$} & $p$-value \\
\hline Constant & -4.449 & 0.106 \\
ROA & -0.629 & 0.802 \\
LEV & -0.307 & 0.603 \\
SLACK & 0.059 & 0.459 \\
REPUT & 5.038 & $0.000^{* *}$ \\
BSIZE & 0.682 & $0.007^{* *}$ \\
CEOEXP & -0.813 & 0.475 \\
BEXP & 2.083 & 0.449 \\
NEWNESS & 1.581 & 0.407 \\
CAPIN & -0.365 & 0.307 \\
$N$ & 100 & \\
Model F stat & 3.470 \\
Adj. $R^{2}$ & $0.190^{* *}$ \\
\hline \multicolumn{2}{c}{ *Significance level (two-tailed) at the 5\% level. } \\
**Significance level (two-tailed) at the 1\% level \\
\multicolumn{2}{r}{ Table 6: Results of the OLS regression }
\end{tabular}

\section{CONCLUSION}

This study examines the extent of energy disclosures among the largest energy intensive companies in Malaysia and the factors influencing the disclosure practices. Overall, there is a low level of disclosure on energy among the companies. This provides several implications. First, considering that the sample companies are from the energy intensive industries, this situation is alarming. In the age of climate change, public would like to know what initiatives companies have taken to mitigate, and adapt to, this problem. Such a low disclosure among the sample companies might indicate the overall level of disclosure of companies in Malaysia. Second, the findings of this study also suggest that, if left alone, companies in Malaysia would not disclose beyond what is required by the laws and accounting standards. The disclosure of environmental information (including energy related), although is mandatory, the volume, nature and type are very much the discretion of the companies. This might suggest for more refined guideline for reporting to ensure a more comprehensive, comparable and consistent information.

The findings should be interpreted with caution. Firstly, the sample size is small and the industry is limited. Future studies might consider increasing the sample size and including companies from low energy intensive industries to enhance the generalizability of the findings. Secondly, the measure for energy reporting only considers the quantity of information being reported (i.e. occurrence). The examination of quality of such information, either quantitative or qualitative, might provide better understanding of the disclosure practice. Finally, we have not considered the influence of physical resources (e.g., total assets) and human capabilities (e.g., board age, board tenure). The inclusion of these additional variables is expected to improve the ability of the regression model to explain the variation in the disclosure. 


\section{REFERENCES:}

Abdullah, S. N., Mohamad, N. R., \& Mokhtar, M. Z. (2011). Board independence, ownership and CSR of Malaysian large firms, Corporate Ownership \& Control, 8(3), 417-431.

Ahmad, N. N. N., Sulaiman, M., \& Siswantoro, D. (2003). Corporate social responsibility disclosure in Malaysia: An analysis of annual reports of KLSE listed companies. International Journal of Economics, Management and Accounting, 11(1), 51-86.

Akbas, H. E., \& Canikli, S. (2014). Corporate environmental disclosures in a developing country: An investigation on Turkish listed companies, International Journal of Economics and Finance, 6(2), 50-61.

Al-Mofleh, A., Taib, S., Mujeebu, M. A., \& Salah, W. (2009), Analysis of sectoral energy conservation in Malaysia. Energy, 34(6), 733-739.

Amran, A., Ooi, S. K., Wong, C. Y., \& Hashim, F. (2016). Business Strategy for Climate Change: An ASEAN Perspective, Corporate Social Responsibility and Environmental Management, 23(4), 213-227.

Arshad, R., Omar, H., \& Othman, R., (2012). Corporate resources and environmental reporting practices in Malaysia, 3rd International Conference on Business and Economic Research Proceeding, 12 - 13 March.

Bansal, P. (2005). Evolving sustainably: a longitudinal study of corporate sustainable development, Strategic Management Journal, 26(3), 197-218.

Barney, J. (1991). Firm resources and sustained competitive advantage, Journal of Management, 17(1), 99-120.

Bassi, A. M., \& Yudken, J. S. (2011). Climate policy and energy-intensive manufacturing: A comprehensive analysis of the effectiveness of cost mitigation provisions in the American Energy and Security Act of 2009, Energy Policy, 39(9), 4920-4931.

Bassi, A. M., Tan, Z., \& Mbi, A. (2012). Estimating the impact of investing in a resource efficient, resilient global energy-intensive manufacturing industry, Technological Forecasting and Social Change, 79(1), 69-84.

Branco, M. C., \& Rodrigues, L. L. (2006), Corporate social responsibility and resource-based perspectives, Journal of Business Ethics, 69(2), 111-132.

Buniamin, S. (2010). The quantity and quality of environmental reporting in annual report of public listed companies in Malaysia. Issues in Social \& Environmental Accounting, 4(2), 115-135.

Buniamin, S., Alrazi, B., Johari, N.H., \& Abd. Rahman, N.R. (2008). An investigation of the association between corporate governance and environmental reporting in Malaysia, Asian Journal of Business and Accounting, 1(2), 65-88.

Campana, F., Bianchi, M., Branchini, L., De Pascale, A., Peretto, A., Baresi, M., \& Vescovo, R. (2013). ORC waste heat recovery in European energy intensive industries: Energy and GHG savings, Energy Conversion and Management, 76, 244-252.

Campbell D., Craven B., \& Shrives P., (2003), Voluntary social reporting in three FTSE sectors: A comment on perception and legitimacy, Accounting, Auditing, and Accountability Journal, 16, 558-591.

Cao, Y., Myers, L. A., \& Omer, T. C. (2012). Does company reputation matter for financial reporting quality? Evidence from restatements, Contemporary Accounting Research, 29(3), 956-990.

Carpenter, M. A., Sanders, W. G., \& Gregersen, H. B. (2001). Bundling human capital with organizational context: The impact of international assignment experience on multinational firm performance and CEO pay, Academy of Management Journal, 44(3), 493-511. 
Clarkson, P. M., Li, Y., Richardson, G. D., \& Vasvari, F. P. (2008). Revisiting the relation between environmental performance and environmental disclosure: An empirical analysis, Accounting, Organizations and Society, 33(4), 303-327.

Darus, F., Mad, S., \& Yusoff, H. (2014), The importance of ownership monitoring and firm resources on corporate social responsibility (CSR) of financial institutions, ProcediaSocial and Behavioral Sciences, 145, 173-180.

Das, T. K., \& Teng, B. S. (2000). A resource-based theory of strategic alliances, Journal of Management, 26(1), 31-61.

De Aguiar, T. R. S., \& Bebbington, J. (2014), Disclosure on climate change: Analysing the UK ETS effects, Accounting Forum, 38, 227-240.

Elsayed, K. (2006). Reexamining the expected effect of available resources and firm size on firm environmental orientation: An empirical study of UK firms, Journal of Business Ethics, 65(3), 297-308.

Field, A. (2013), Discovering Statistics using IBM SPSS Statistics (4th ed.), SAGE Publications: London.

Ienciu, I. A., Popa, I. E., \& Ienciu, N. M. (2012). Environmental reporting and good practice of corporate governance: Petroleum industry case study, Procedia Economics \& Finance, 3, 961-67.

International Energy Outlook, (2014). World energy and economic outlook. Retrieved at: http://www.eia.doe.gov/oiaf/ieo/world.html

Kansal, M., Joshi, M., \& Batra, G. S. (2014). Determinants of corporate social responsibility disclosures: Evidence from India, Advances in Accounting, 30(1), 217-229.

Levesque, M., Millar, D., \& Paraszczak, J. (2014). Energy and mining-the home truths. Journal of Cleaner Production, 84, 233-255.

Li, L., Wang, J., Tan, Z., Ge, X., Zhang, J., \& Yun, X. (2014). Policies for eliminating lowefficiency production capacities and improving energy efficiency of energy-intensive industries in China. Renewable and Sustainable Energy Reviews, 39, 312-326.

Liddle, B., (2012). The importance of energy quality in energy intensive manufacturing: Evidence from panel cointegration and panel FMOLS. Energy Economics. 34, 18191825.

Lin, B., \& Xie, C. (2014). Reduction potential of $\mathrm{CO}_{2}$ emissions in China' s transport industry. Renewable and Sustainable Energy Reviews, 33, 689-700.

Luo, L., Tang, Q., \& Lan, Y. C. (2013). Comparison of propensity for carbon disclosure between developing and developed countries: A resource constraint perspective, Accounting Research Journal, 26(1), 6-34.

Maneschijn, R., Vosloo, J.C., Pelzer, R. (2014). Effective multi-level energy reporting in South African industry, International Conference on the Industrial and Commercial Use of Energy (ICUE), 19-20 Aug.

Michelon, G., \& Parbonetti, A. (2012). The effect of corporate governance on sustainability disclosure. Journal of Management \& Governance, 16(3), 477-509.

Mohamad Taha, M.H. (2013). The relationship between corporate social responsibility disclosure and corporate governance characteristics in Malaysian public listed companies. Retrieved from http://papers.ssrn.com/sol3/papers.cfm?abstract_id=2276763

Napp, T. A., Gambhir, A., Hills, T. P., Florin, N., \& Fennell, P. S. (2014). A review of the technologies, economics and policy instruments for decarbonising energy-intensive manufacturing industrie, Renewable and Sustainable Energy Reviews, 30, 616-640.

Nohria, N., \& Gulati, R. (1996). Is slack good or bad for innovation? Academy of Management Journal, 39(5), 1245-1264. 
Othman, R. \& Ameer, R. (2009). Corporate social and environmental reporting: Where are we heading? A survey of the literature. International Journal of Disclosure and Governance, 6, 298-320

Palamutcu, S. (2010). Electric energy consumption in the cotton textile processing stages. Energy, 35(7), 2945-2952.

Paramonova, S., Thollander, P., \& Ottosson, M. (2015). Quantifying the extended energy efficiency gap-evidence from Swedish electricity-intensive industries, Renewable and Sustainable Energy Reviews, 51, 472-483.

Qiu, Y., Shaukat, A., \& Tharyan, R. (2014). Environmental and social disclosures: Link with corporate financial performance. The British Accounting Review, 48(1), 102-116.

Russo, M. V., \& Fouts, P. A. (1997). A resource-based perspective on corporate environmental performance and profitability, Academy of management Journal, 40(3), 534-559.

Saidur, R., Masjuki, H. H., Jamaluddin, M. Y., \& Ahmed, S. (2007). Energy and associated greenhouse gas emissions from household appliances in Malaysia, Energy Policy, 35(3), 1648-1657.

Saleh, M., Zulkifli, N., \& Muhamad, R. (2010), Corporate social responsibility disclosure and its relation on institutional ownership: Evidence from public listed companies in Malaysia, Managerial Auditing Journal, 25, 591-613.

Saygin, D., Worrell, E., Patel, M. K., \& Gielen, D. J. (2011). Benchmarking the energy use of energy-intensive industries in industrialized and in developing countries. Energy, 36(11), 6661-6673.

Slater, D. J., \& Dixon-Fowler, H. R. (2009). CEO international assignment experience and corporate social performance, Journal of Business Ethics, 89(3), 473-489.

Song, C., \& Oh, W. (2015). Determinants of innovation in energy intensive industry and implications for energy policy. Energy Policy, 81, 122-130.

International Energy Agency (2013). Southeast Asia Energy Look. Retrieved at https://www.iea.org/publications/freepublications/publication/SoutheastAsiaEnergyOutlo ok_WEO2013SpecialReport.pdf

Sulaiman M., Abdullah N., \& Abdul Hamid, F. (2014), Determinants of environmental reporting quality in Malaysia, International Journal of Economics, Management, \& Accounting, 22, 63-90.

Suutari, V., \& Mäkelä, K. (2007). The career capital of managers with global careers. Journal of Managerial Psychology, 22(7), 628-648.

Toms, J. S. (2002). Firm resources, quality signals and the determinants of corporate environmental reputation: some UK evidence, The British Accounting Review, 34(3), 257-282.

Toppinen, A., Li, N., Tuppura, A., \& Xiong, Y. (2012). Corporate responsibility and strategic groups in the forest-based industry: Exploratory analysis based on the Global Reporting Initiative (GRI) framework. Corporate Social Responsibility and Environmental Management, 19(4), 191-205.

Unerman, J. (2000). Methodological issues-reflections on quantification in corporate social reporting content analysis. Accounting, Auditing \& Accountability Journal, 13(5), 667681.

Wei, L. Q., \& Ling, Y. (2015). CEO characteristics and corporate entrepreneurship in transition economies: Evidence from China, Journal of Business Research, 68(6), 11571165.

Wright, P. M., \& McMahan, G. C. (1992), Theoretical perspectives for strategic human resource Management, Journal of Management, 18(2), 295-320. 
Yol Lee, S., \& Rhee, S. K. (2007). The change in corporate environmental strategies: a longitudinal empirical study, Management Decision, 45(2), 196-216.

Zeng, S. X., Xu, X. D., Yin, H. T., \& Tam, C. M. (2012). Factors that drive Chinese listed companies in voluntary disclosure of environmental information, Journal of Business Ethics, 109(3), 309-321. 